\title{
Lena Bielska, review of: Electronic democracy. Controversies and dilemmas, ed. Maria Marczewska-Rytko, Maria Curie-Sklodowska University Press, Lublin 2013, p. 319.
}

The reviewed publication is the collective monograph from the series "Direct Democracy" published by the Department of Political Movements of the Faculty of Political Science of the Maria Curie-Skłodowska University. So far in this series of books the following titles were published: Direct democracy in theory and political practice, Condition and prospects of direct democracy in Poland, Direct democracy. The global and local dimension, Status and prospects of direct democracy in the contemporary world, Direct democracy and local government. E-democracy is a book that raises the question of democracy in the context of a new social order in which the presence of electronic communication is the basis of social Web 2.0. The book, divided into four parts, contains articles of the UMCS faculty. In the first part $-E-d e-$ mocracy - theoretical dimension - Maria Marczewska-Rytko introduces the issue of electronic democracy; Leszek Porębski contests electronic dimension of democracy; Marcin Rachwał compares electronic democracy and political participation of citizens; Rafał Brzoza takes on electronic democracy as a process of virtualization, medialization and simulacrization of socio-political processes. In the second part - E-democracy - practical dimension - Magdalena Musiał-Karg describes the main issues of e-voting; Marta Du Vall discusses the phenomenon of citizen hacking in the context of social changes in the twenty-first century; Justyna Cywoniuk takes on modern surveillance systems as a way to deal with the threats of national security; Jakub Nowak writes about the social opposition to ACTA as an example of active citizenship and participation in popular culture. The second part is closed by the article by Marek Miłek about electronic democracy in terms of social policy directed towards people with disabilities. The third part -E-democracy in the world - selected examples - begins with the article by Marcin Pomarański writing about political agitation on the Internet done by the American Religious Right and its participation in the electoral campaigns in the $21^{\text {st }}$ century; Agnieszka Walecka-Rynduch describes the German Pirate Party; Justyna Olędzka discusses the role of the Internet in the process of legitimization and delegitimization of Vladimir Putin's political leadership; Marta Drabchuk writes about the perspective of e-government for the Ukrainian state administration; Wojciech Ziętara shows the Internet as a source of political participation using Poland and the United States of America as an example. The fourth part of the book - E-democracy in Poland - selected examples - opens with Janina Kowalik's article which examines the issue of political polls and democracy; Krystyna Leszczyńska discusses the adaptation of the Polish government's structure to implement e-government; Dorota Maj takes on the analysis of netarchy - a political system that emphasizes the development of individuals and social groups. The last item is the article by Tomasz Gajowniczek, showing the example of electronic democracy in Olsztyn's municipalities.

Table of contents is placed at the beginning of the book, followed by an introduction by Maria Marczewska-Rytko. At the end of the book more info about the authors can be found. Since the publication is divided into four parts: theory, practice and selected examples from Poland and the world, main problems with research from the individual work shall be indicated. So, it appears in the first part of the monograph, that information and communication technologies offer a wide range of possibilities for democracy. A process of improving the communication of these systems 
is advanced - the United States of America is given as an example. Nevertheless, the change of the current model of democracy requires participation of the part of society. Inducing the participation seems like a more significant obstacle, than the advancement of new technology. In the part relating to the practical dimensions of the subject, the following thesis were mentioned: the need to implement e-voting, as the most important tool of e-democracy; cyber crime, as a consequence of the development of information technology. Another thesis states that modern technologies promote freedom, choice, transparency and personalization of social needs. As an example of struggle for freedom using the Internet, authors brought up the action of resistance against ACTA. In the part dedicated to examples of global e-democracy, there are shown the examples of American Religious Right cooling down its rhetoric in the context of contemporary virtual culture and German political scene becoming more colorful after appearance of German Pirate Party. The challenges for democracy beyond our eastern border were also touched upon. In Russia, the process of virtualization of politics and social life seems to slow and does not promise positive outcomes. Also Ukraine trying to speed up its integration with EU started to implement the standards of e-democracy. Despite many difficulties, the benefits of those actions are noticeable. The last part of the book introduces examples of e-democracy in Poland. One of them is contradictory of a thesis that political polls are harmful to democracy. The process of medialisation of society and increasing competition among media, contribute to negative reception of the polls. Moreover, the Polish government began a series of actions aimed at computerizing management. However, Poland is still on a distant place in this domain, according to international reports. Also the netarchy does not seem to constitute a threat to representative democracy, but could introduce innovative solutions and improve the functioning of social and political order.

Publication of E-democracy-controversies and dilemmas is an interesting addition to the set of "direct democracy". Even more so, that it opens up new insights and research issues around democracy in the context of new technologies and the development of electronic communication. So far, on the Polish market appeared very few publications dealing with related activity. One of the most important books on the subject were edited by Marta Du Vall and Agnieszka Walecka-Rynduch. The publication's scope of interest revolves around contemporary political scene and media in the context of political campaigns. Another important book on the subject is a monograph by Maria Nowina-Konopka about the role of the Internet in the development of Polish democracy. Also, in 1997, the translation of a well-known among IT professionals Graeme Browning's book was published.

The strong point of the reviewed book is also a clear division into theoretical models and practical examples from Poland and from around the world. E-democracy is a very broad topic and taking into account that this book is one of the few items concerned with the subject, we can consider it as a prelude to more in-depth analysis of this issue. It should be added that the articles contained in this publication are rich in various forms of data, like graphics, tables and charts, giving the reader even easier and closer context of new technologies and cyber democracy. In its form and language it is close to electronic communication forms, social media and contemporary journalism.

E-democracy-controversies and dilemmas brings a lot of fresh and new ideas for research in the field of social and political movements. It is one of the few Polish publishing proposals intruding in this area. Further research, according to the division introduced in the book, indepth analysis and collecting the findings in the publisher series "Direct Democracy" seem like an interesting opportunity. 
Given the extremely rapid development of technologies and implementation of the communication systems in the social and political sphere, the part dealing with a practical electronic democracy, seems to be particularly interesting. Nevertheless, the book edited by Maria Marczewska-Rytko is a valuable publication for researchers from many faculties. It may be helpful especially in the field of journalism and social sciences, which deal with complex processes, both social and political. Written in a very accessible and clear manner, it should be helpful both for the people involved in the theory as well as practice, in the field of cyber democracy and new information technologies. 